Article

\title{
Environmental Impacts of Photoluminescence and Light-Emitting Diode (LED) Lighting Technologies in Horticulture: Case Study on Compact Fluorescent Lamp (CFL) and LED Lights for "Night Break" of Chrysanthemum Cultivation
}

\author{
Thi Thu Linh Hoang ${ }^{1,2, *}$, Thi Gam Do ${ }^{1}$, Van Thao Nguyen ${ }^{1}$, Hoai Chau Nguyen ${ }^{2,3}$ \\ and Hong Khoi Phan $1, *$ \\ 1 Center for High Technology Development, VAST, Hanoi 10000, Vietnam; honggam@htd.vast.vn (T.G.D.); \\ thaonv@vast.vn (V.T.N.) \\ 2 Faculty of Environmental Technology, Graduate University of Science \& Technology (GUST), VAST, \\ Hanoi 10000, Vietnam; nhchau.iet@gmail.com \\ 3 Institute of Environmental Technology (IET), VAST, Hanoi 10000, Vietnam \\ * Correspondence: thulinh@htd.vast.vn (T.T.L.H.); phkhoi@htd.vast.vn (H.K.P.); \\ Tel.: +84-98-3416689 (T.T.L.H.); Fax: +84-24-3791-6283 (T.T.L.H.)
}

Received: 7 August 2020; Accepted: 17 September 2020; Published: 25 September 2020

\begin{abstract}
The environmental impacts of photoluminescence and light-emitting diode (LED) lighting technologies in horticulture are described in this paper. As a case study, the life cycle assessment (LCA) associated with the raw materials, air, water and natural resources of screw-based compact fluorescent lamps (CFLs) and screw-based horticultural LED lamps (abbreviated as H-LED) used for "night break" effect in chrysanthemum cultivation is considered. Instead of the unit of radiant power of lighting sources (lumens) used in human lighting, the photon flux (micromoles per second) of the plant light is used in this study. The results of the study show that the environmental impacts of the H-LED lighting technology are markedly less than the fluorescent lamps. Therefore, the shift to LED lighting technology in horticulture in general, and "night break" chrysanthemum cultivation in particular, brings about tremendous benefits not only for saving energy and improving crop quality, but also for protecting the air/climate, water, soil and natural resources.
\end{abstract}

Keywords: artificial light; CFL; LED; horticulture; chrysanthemum; air/climate; water; soil; natural resources

\section{Introduction}

Electric lamps, such as fluorescent lamps, are widely used to supplement sunlight (supplemental lighting) and day-length extension (photoperiodic lighting) for the production of horticultural crops in greenhouses. Recent advances in light-emitting diode (LED) technology now provide the horticultural industry with multiple lighting options. However, to our knowledge, almost all of the previous studies of artificial lights focused only on the evaluation of effectiveness and energy saving of the different kinds of lamps, including horticultural light emitting diode (H-LED) lights used for horticultural applications [1-8]. These studies neglected to examine the influence of artificial lighting sources on the environment associated with four environmental categories: air/climate, water, soil and resources. However, reduced environmental impact is one of the major selling points of artificial lighting sources and an in-depth environmental impact study is initiated in our study. Life cycle assessment (LCA) was used because it is an approach well-suited for comparing the environmental impacts of the traditional 
lighting sources with H-LED lighting. It provides an excellent methodology to answer the question "Is the proposed H-LED light better for the environment than the traditional light?". To respond to this question, a case study on the environmental impacts of compact fluorescent lamps (CFL) and H-LED lights for night break of chrysanthemum cultivation was carried out.

Chrysanthemum is one of the most important cut flowers and has the highest consumption in the world. As a short-day plant (SDP), wild type chrysanthemum flowers in autumn under natural conditions. In other words, chrysanthemum flowers when night length exceeds a critical dark period. By interrupting the dark period by a brief light treatment through "night break" (NB), flowering in SDPs is prevented. This method of farming helps chrysanthemum flowers bloom on specific days with bulky flowers, beautiful petals, while being able to be sold at higher prices. Previously, in order to inhibit early flowering, for example from autumn to winter, chrysanthemum growers applied NB lighting by using incandescent (INC) bulbs. However, the use of incandescent bulbs prevents flowering and consumes a lot of electricity because of its very low electrical to light energy transformation efficiency. Currently, to save energy, flower planters have shifted to using compact fluorescent lamps (CFLs).

Da Lat City (Vietnam) has approximately 2500 ha for the cultivation of various types of daisies and chrysanthemums. Every year, the gardeners use 20-25 W CFLs for lighting at an average density rate of 1000 CFLs/ha, at a frequency of about 4-6 lighting hours per night, 35 nights per harvest and 4 harvests per year. Therefore, the total power consumption across the region is about $29-47$ million kilowatt hours per year with a monetary value of electricity at about VND 35-66 billion per year, equivalent to about USD 1.5-2.8 million per year (assuming the 2019 electricity price and the Vietnam dong (VND)/USD exchange rate are $\approx \mathrm{VND} 1200 / \mathrm{kWh}$, and $\approx 23,000$, respectively). Therefore, many farmers who produce chrysanthemum cuttings in greenhouses in Da Lat City and surrounding areas, have boldly replaced the compact lamp lighting systems with H-LED lighting. The test results from using $5 \mathrm{~W}-10 \mathrm{~W}$ H-LED lights on some acreage of Da Lat chrysanthemum farms shows that the chrysanthemum absorbs the light, which controls flowering well, saving up to half the energy costs compared to the use of 20-25 W compact fluorescent light.

As seen in Figure 1, the nonilluminated chrysanthemum bed flowered well after 40 days and was harvested after 68 days of growth. Meanwhile, the illuminated chrysanthemum bed did not flower after 40 days and was harvested only after 100 days of growing. In addition, the height of the chrysanthemum plants when illuminated was superior to that when it was not illuminated. Compared to the case using CFL lamps, the height of chrysanthemum plants and the flower dimensions were higher and larger when illuminated by H-LED lights.

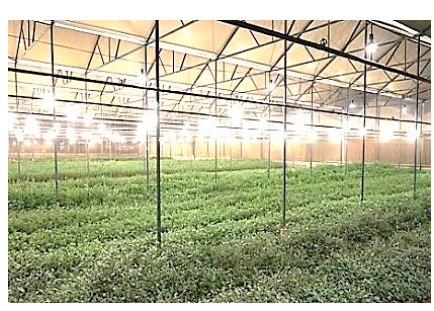

(a)

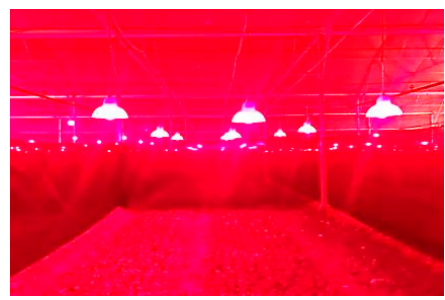

(b)

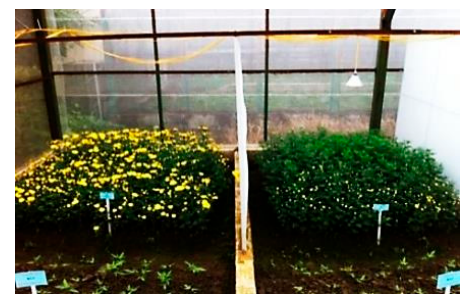

(c)

Figure 1. (a) A greenhouse equipped with compact fluorescent lamps (CFLs) to cultivate chrysanthemum in Da Lat City, Vietnam, (b) horticultural light emitting diode (H-LED) lights used for "night break" of the chrysanthemum, and (c) testing nonilluminated chrysanthemum bed (left) and H-LED illuminated chrysanthemum bed (right) after 40 days of growth.

\section{Method and Materials}

\subsection{LCA Methodology}

The diagram in Figure 2 illustrates the system boundary, four stages, inputs and outputs (environmental impacts) used for the life cycle assessment of CFLs and H-LED lights. 


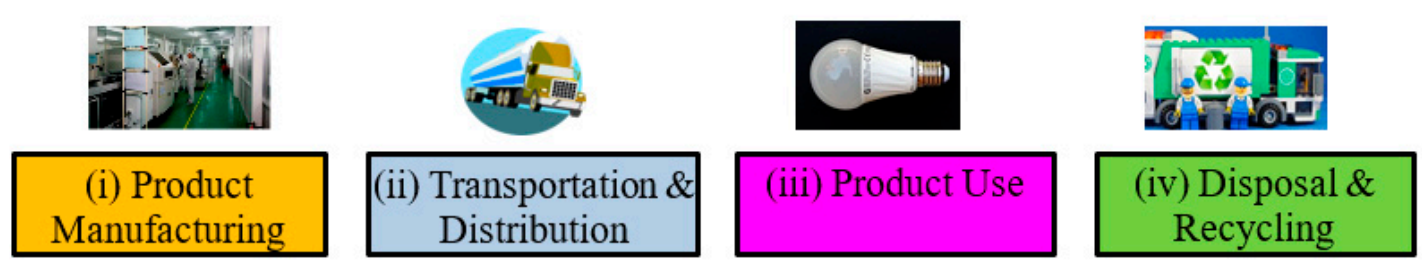

Inputs: Raw materials, water consumption, energy resources, energy, and products
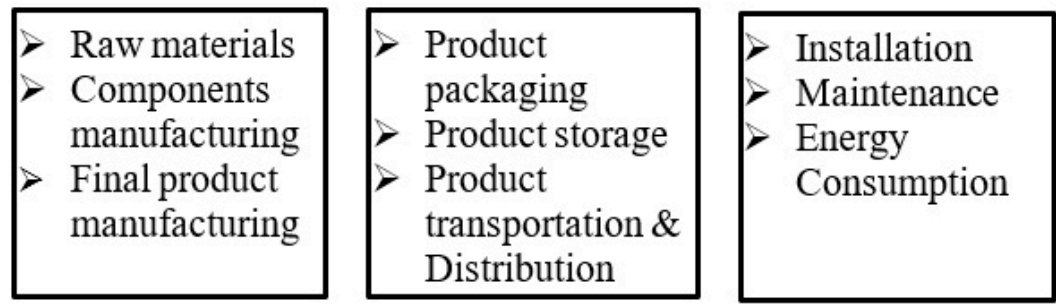

Transport to waste disposal facility Recycling process

\section{Outputs (Environmental impacts): Emission to air, emission to water, emission to soil, energy consumption, and waste}

Figure 2. Scope, four stages, inputs and outputs of life cycle assessment (LCA).

As shown in Figure 2, the impact inventories were broken down into four life cycle phases, which include (i) manufacturing (inputs, raw materials, components manufacturing and final product manufacturing), (ii) transportation and distribution to point of sale, (iii) use of the product, and (iv) end-of-life disposal/recycling.

Since the environmental impacts related to the transport phase associated with shipping/distribution from the manufacturer to the consumer are negligible, phase 2 of the life cycle was not included in this study. The disposal/recycling phase (4) was also omitted because fluorescent lamps containing mercury are considered hazardous waste, so the current treatment depends heavily on consumer consciousness and local government regulations.

\subsection{Indicators of Environmental Impact}

Fifteen indicators chosen for this study are summarized in the Table 1. These fifteen indicators are associated with four environmental categories: air/climate, water, soil and resources.

In Table 1, the last column identifies the units in which each of these environmental indicators were measured. For example, global warming is attributed to a number of gases, including carbon dioxide $\left(\mathrm{CO}_{2}\right)$ and methane $\left(\mathrm{CH}_{4}\right)$; however, emissions are reported for this indicator simply in units of " $\mathrm{kg}$ of $\mathrm{CO}_{2}$ equivalents". On that basis, $\mathrm{CO}_{2}$ is said to have a global warming potential (GWP) of one because $1 \mathrm{~kg}$ of $\mathrm{CO}_{2}$ has the warming potential of itself, but methane has a GWP of $25(1 \mathrm{~kg}$ of $\mathrm{CH}_{4}$ has the warming potential of $25 \mathrm{~kg}$ of $\mathrm{CO}_{2}$ ). By using equivalent values, the outputs of the LCA are simplified, which facilitates better comparisons between studies. Several other criteria were reported in a similar way, notably the toxicity criteria, which were assessed relative to the toxicity of 1.4-DiChloroBenzene (1.4-DCB), a known carcinogenic substance $[9,10]$.

\subsection{Light Selection and Function Unit Definition}

Our study was narrowed to scope the environmental impacts of just 25 W CFLs and 7 W H-LED lamps. All CFLs and H-LED lamps were produced by Tuan Khuong and Dien Quang Lamp Joint Stock Companies as shown in Figure 3 below. 
Table 1. Environmental indicators selected for this analysis [9].

\begin{tabular}{|c|c|c|c|}
\hline Name & Abbr. & Indicator & Measurement Units \\
\hline \multicolumn{4}{|l|}{ Air/Climate } \\
\hline Global warming potential & GWP & Greenhouse gas emissions & $\mathrm{kg} \mathrm{CO}_{2}$-eq. * \\
\hline Acidification potential & $\mathrm{AP}$ & Air pollution & $\mathrm{kg} \mathrm{SO}_{2}$-eq. \\
\hline Photochemical ozone creation potential & POCP & Air pollution & $\mathrm{kg} \mathrm{O}_{3}$ formed \\
\hline Ozone depleting potential & ODP & Air pollution & kg CFC11-eq. \\
\hline Human toxicity potential & HTP & Toxicity & kg 1.4-DCB-eq. \\
\hline \multicolumn{4}{|l|}{ Water } \\
\hline Freshwater aquatic eco-toxicity potential & FAETP & Water pollution & kg 1.4-DCB-eq. \\
\hline Marine aquatic eco-toxicity potential & MAETP & Water pollution & kg 1.4-DCB-eq. \\
\hline Eutrophication potential & EP & Water pollution & $\mathrm{kg} \mathrm{PO}_{4}$-eq. \\
\hline \multicolumn{4}{|l|}{ Soil } \\
\hline Land use & LU & \multirow{3}{*}{$\begin{array}{c}\text { Land use } \\
\text { Biodiversity impacts } \\
\text { Soil degradation and } \\
\text { contamination }\end{array}$} & $\mathrm{m}^{2} \mathrm{a}$ \\
\hline Ecosystem damage potential & EDP & & Points \\
\hline Terrestrial eco-toxicity potential & TAETP & & kg 1.4-DCB-eq. \\
\hline \multicolumn{4}{|l|}{ Resources } \\
\hline Abiotic resource depletion & ARD & Resource depletion & kg Sb-eq. \\
\hline Nonhazardous waste landfill & NHWL & Nonhazardous waste & kg waste \\
\hline Radioactive waste landfill & RWL & Hazardous waste & kg waste \\
\hline Hazardous waste landfill & HWL & Hazardous waste & kg waste \\
\hline
\end{tabular}

* The abbreviation "eq." stands for equivalents which will often be used when more than one pollutant can cause a particular impact.
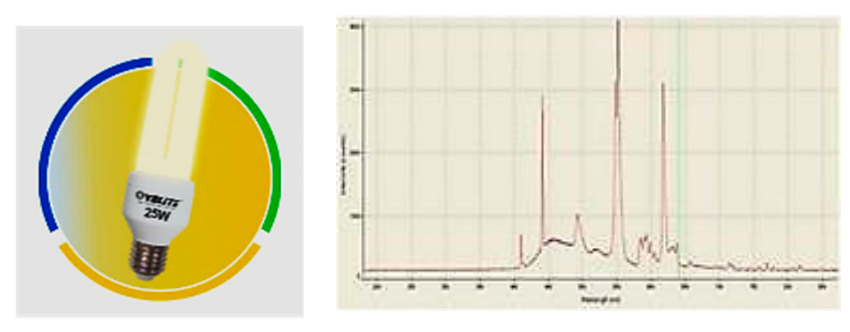

(a)

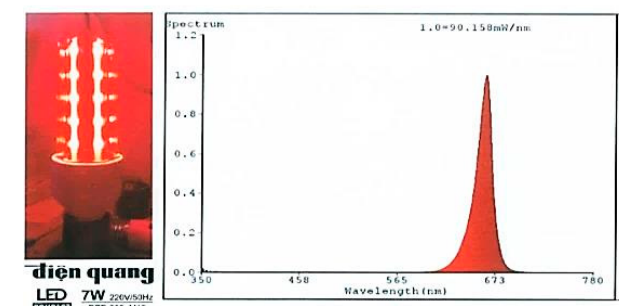

(b)

Figure 3. Pictures and light spectrum of (a) the CFL 3U-25 W, and (b) H-LED 3U-R660-7 W lights used in studying the night break of chrysanthemum.

The study was associated with the lamps only, and not those associated with the fixtures, electrical hook ups and other necessary lighting components for CFLs or drivers for screw-based H-LED lamps. After the environmental impacts from each individual lamp were assessed and analyzed, the results were compiled in order to discuss the impacts of an entire lighting system.

Note that the lighting for plants is different from lighting for humans. Light energy for humans is measured in lumens, with light falling onto a surface measured as luminance with units of lux (lumens per square meter) or foot candles (lumens per square foot). Light energy for plants on the other hand, is measured in $\mu \mathrm{mol} / \mathrm{s}$ - the photosynthetic photon fluxes (PPF) or with light falling onto a surface measured as $\mu \mathrm{mol} / \mathrm{s} . \mathrm{m}^{-2}$ (photosynthetic photon flux density (PPFD)).

Considering the light output and lifetime for each lamp, it is apparent that these products are not perfectly equivalent. For human lighting to provide the uniformity necessary to conduct a life cycle energy analysis, the functional unit of "lumen-hours" has been used. However, for plant illumination, instead of the functional unit of "lumen-hours" used for human illumination, we propose to introduce another functional unit, called "( $\mu \mathrm{mol} / \mathrm{s})$-hours". This functional unit represents the lighting service provided by a single $7 \mathrm{~W}$ LED lamp with an average PPF of $11.7(\mu \mathrm{mol} / \mathrm{s})$ over its 20,000 $\mathrm{h}$ lifetime, i.e., $234,000 \mu \mathrm{mol} / \mathrm{s}-\mathrm{h}$. 
Characteristics of CFL 3U-25 W and H-LED 3U-R660-7 W lamps used for the illumination of the $1000 \mathrm{~m}^{2}$ chrysanthemum field are given in the Table 2.

Table 2. Characteristics of compact fluorescent lamps (CFLs) and horticultural light emitting diode (H-LED) lamps used for night break of chrysanthemum.

\begin{tabular}{ccc}
\hline Characteristics & CFL & H-LED \\
\cline { 2 - 3 } & $\mathbf{( 3 U - 2 5 ~ W ) ~}$ & $\mathbf{( 3 U - R - 7 ~ W ) ~}$ \\
\hline Power consumption/lamp $(\mathrm{W})$ & 25 & 7 \\
Photosynthetic active radiation $(\mathrm{PAR})$ output $(\mu \mathrm{mol} / \mathrm{s})$ & 13.3 & 11.7 \\
Efficacy $(\mu \mathrm{mol} / \mathrm{s}) / \mathrm{W}$ & 0.53 & 1.67 \\
Lamp lifetime $($ hours $)$ & 10,000 & 20,000 \\
Total lifetime PAR output $(\mu \mathrm{mol} / \mathrm{s})-\mathrm{h}$ & 133,000 & 234,000 \\
Number of lamps needed to supply $234,000(\mu \mathrm{mol} / \mathrm{s})-\mathrm{h}$ & $\approx 1.8$ & $\approx 1.0$ \\
Number of lamps needed for illuminating $1000 \mathrm{~m}^{2}$ of greenhouse $(\mathrm{lamp})^{1}$ & 255 & 145 \\
Total power consumption $(\mathrm{kWh})$ used for illuminating $1000 \mathrm{~m}^{2}$ of greenhouse in $20,000 \mathrm{~h}$ & 63,750 & 20,300 \\
\hline
\end{tabular}

${ }^{1} 1000 \mathrm{~m}^{2}$ is the average area of the greenhouse or chrysanthemum field in Vietnam.

\subsection{Life Cycle Inventory (LCI) Data Conversion}

According to the assumption reported in [11,12], for the raw materials extraction and manufacturing periods, the environmental impacts are approximately proportional to the mass of lamps, and life cycle inventory (LCI) data in this study can be found by using lamp mass conversion factors. The average mass of the CFL $15 \mathrm{~W}$ lamps used in [10] and the CFL 3U-25 W lamps used in this study, was $234 \mathrm{~g}$ and $146 \mathrm{~g}$, respectively. Therefore, LCI data for the screw-based CFL 3U-25 W was multiplied by a conversion factor of 0.62 . Similarly, for LED lamps, there was a big difference in average mass of LED $12.5 \mathrm{~W}$ (215 g) used in [9], and H-LED 3U-R660-7 W (142 g) lamps used in this study. Thus, LCI data for the screw-based H-LED 3U-R660-7 W was multiplied by a conversion factor of 0.66 .

For the use period, the amount of greenhouse gas emissions and waste generated by CFL $3 \mathrm{U}-25 \mathrm{~W}$ lights was determined by multiplying a corresponding lifetime energy consumption conversion factor of two lamps. A similar approach was applied for the H-LED 3U-R660-7 W lights. In addition, it should be taken into account the difference between the emission factor used in [11] and in our case. The $\mathrm{CO}_{2}$ emission factor of Vietnam's electricity grid was $0.913 \mathrm{t} \mathrm{CO}_{2} / \mathrm{MWh}$ [13], while the US emission factor was 0.69 tons $\mathrm{CO}_{2} / \mathrm{MWh}$ [10], therefore, the $\mathrm{CO}_{2}$ emission conversion factor was 1.3, which was multiplied by the global warming index.

\section{Results and Discussion}

Table 3 below presents the environmental impacts associated with air and climate for each of the lamp types. Within each of the impact indicators, the values presented are comparable between the different lamp types because the lighting service was normalized to represent $234,000 \mu \mathrm{mol} / \mathrm{s}-\mathrm{h}$ for the H-LED lamp.

For global warming potential (GWP), the CFL had $\mathrm{CO}_{2}$-equivalent emissions, with $1534 \mathrm{~kg}$ of emissions associated with the functional unit of $234,000 \mu \mathrm{mol} / \mathrm{s}-\mathrm{h}$ of light. The H-LED lamps were better, offering only $147.4 \mathrm{~kg}$ of $\mathrm{CO}_{2}$-equivalent emissions.

For acidification potential (AP), the trend was similar. The CFL caused the most impact, with $8.33 \mathrm{~kg}$ of sulfur dioxide-equivalent emissions for $234,000 \mu \mathrm{mol} / \mathrm{s}-\mathrm{h}$ of light. The H-LED lamps offered only $0.82 \mathrm{~kg}$ of sulfur dioxide, greatly reducing the acidification potential. 
Table 3. Air-related environmental impacts of the CFL and H-LED lamps for $234,000 \mu \mathrm{mol} / \mathrm{s}-\mathrm{h}$ of lighting service.

\begin{tabular}{|c|c|c|c|c|c|}
\hline \multirow{3}{*}{$\begin{array}{c}\text { Life Cycle } \\
\text { Assessment (LCA) } \\
\text { Phase }\end{array}$} & $\begin{array}{c}\text { Global } \\
\text { Warming } \\
\text { Potential }\end{array}$ & $\begin{array}{c}\text { Acidification } \\
\text { Potential }\end{array}$ & $\begin{array}{c}\text { Photochemical } \\
\text { Ozone Creation } \\
\text { Potential }\end{array}$ & $\begin{array}{l}\text { Ozone } \\
\text { Depleting } \\
\text { Potential }\end{array}$ & $\begin{array}{l}\text { Human } \\
\text { Toxicity } \\
\text { Potential }\end{array}$ \\
\hline & (GWP) & (AP) & (POCP) & (ODP) & (HTP) \\
\hline & $\mathrm{kg} \mathrm{CO}$-eq. & kg SO${ }_{2}$-eq. & kg Formed $\mathrm{O}_{3}$ & kg CFC-11-eq. & kg 1.4-DCB-eq. \\
\hline \multicolumn{6}{|c|}{ CFL $3 U-25 \mathrm{~W}$} \\
\hline Raw materials & 13.243 & 0.36239 & 0.003570 & 0.00000145 & 11.169 \\
\hline Manufacturing & 20.534 & 0.10477 & 0.001507 & 0.00000149 & 5.799 \\
\hline Use & $1,500.071$ & 7.86635 & 0.050348 & 0.00001144 & 224.340 \\
\hline Total & $1,533.849$ & 8.33351 & 0.055425 & 0.00001438 & 241.309 \\
\hline \multicolumn{6}{|c|}{ H-LED 3U-R-660-7 W } \\
\hline Raw materials & 8.416 & 0.07842 & 0.001321 & 0.00000090 & 8.766 \\
\hline Manufacturing & 2.277 & 0.02059 & 0.000207 & 0.00000007 & 0.968 \\
\hline Use & 136.722 & 0.71697 & 0.004589 & 0.00000104 & 20.447 \\
\hline Total & 147.415 & 0.81597 & 0.006117 & 0.00000200 & 30.181 \\
\hline
\end{tabular}

Photochemical oxidation potential (POCP) leads to urban smog and the emissions of this air pollutant was the most severe with the CFLs. These lamps emitted approximately $55.42 \mathrm{~g}$ of ozone for the functional unit of light output meanwhile the H-LED lamps only emitted approximately $6.12 \mathrm{~g}$.

For the stratospheric ozone depletion potential (ODP), the CFLs and H-LED lamp emitted $14 \mathrm{mg}$ and $2 \mathrm{mg}$ of CFC-11-eq., respectively.

For human toxicity potential (HTP), the impact for the functional unit of light output was $241.31 \mathrm{~kg}$ of 1.4-DCB-eq. for CFLs and $30.18 \mathrm{~kg}$ of 1.4-DCB-eq. for the H-LED lamps.

Table 4 presents the environmental impacts associated with water-related indicators for each of the lamp types, normalized for $234,000 \mu \mathrm{mol} / \mathrm{s}-\mathrm{h}$ of light output.

Table 4. Water-related environmental impacts of the CFL and H-LED lamp for 234,000 $\mu \mathrm{mol} / \mathrm{s}-\mathrm{h}$ of lighting service.

\begin{tabular}{cccc}
\hline \multirow{2}{*}{ LCA Phase } & $\begin{array}{c}\text { Freshwater Aquatic Eco-Toxicity } \\
\text { Potential (FAETP) }\end{array}$ & $\begin{array}{c}\text { Marine Aquatic Eco-Toxicity } \\
\text { Potential (MAETP) }\end{array}$ & $\begin{array}{c}\text { Eutrophication } \\
\text { Potential (EP) }\end{array}$ \\
\cline { 2 - 4 } & kg 1.4-DCB-eq. & kg 1.4-DCB-eq. & kg PO -eq. $^{-}$ \\
\hline Raw materials & CFL 3U-25 W & 0.13182 \\
\hline Manufacturing & 0.6426 & 8.5669 & 0.04535 \\
\hline Use & 0.4323 & 2.7597 & 2.10974 \\
\hline Total & 21.0558 & 113.0480 & 2.28692 \\
\hline Raw materials & 22.1307 & 124.3747 & 0.05970 \\
\hline Manufacturing & 0.2485 & H-LED 3U-R-660-7 W & 0.00620 \\
\hline Use & 0.0100 & 4.2408 & 0.19229 \\
\hline Total & 1.9191 & 0.2111 & 0.25819 \\
\hline
\end{tabular}

For fresh water aquatic eco-toxicity potential (FAETP), the CFL's impact was more than 10 times higher than the impact of H-LED with over three times the impact. The units for this environmental 
indicator were reported in equivalent kilograms of "1.4-DCB" which is 1.4-Di-ChloroBenzene, a known carcinogen.

For marine aquatic eco-toxicity potential (MAETP), the trend was similar. The CFL had the most impact, with $124.37 \mathrm{~kg}$ of 1.4-DiChloroBenzene equivalent emissions for $234,000 \mu \mathrm{mol} / \mathrm{s}-\mathrm{h}$ of light. The H-LED lamp offered a reduction of only $11.9 \%$ over the CFL, with less than $14.75 \mathrm{~kg}$, greatly reducing this environmental damage potential.

Eutrophication potential (EP) is the last indicator of water-related impacts, and measures the impact in terms of kilograms of phosphate equivalents that could cause excessive algal growth in waterways, reducing oxygen in the water and damaging the ecosystem. The CFL emitted approximately $2.29 \mathrm{~kg}$ of phosphate equivalents over the $234,000 \mu \mathrm{mol} / \mathrm{s}-\mathrm{h}$ lighting service functional unit. The H-LED lamp was approximately $11.3 \%$ less than that with $0.26 \mathrm{~kg}$.

Table 5 presents the environmental impacts associated with soil-related indicators for each of the three lamp types, normalized for $234,000 \mu \mathrm{mol} / \mathrm{s}-\mathrm{h}$ of light output.

Table 5. Soil-related environmental impacts of the CFL and H-LED lamp for 234,000 $\mu \mathrm{mol} / \mathrm{s}-\mathrm{h}$ of lighting service.

\begin{tabular}{cccc}
\hline \multirow{2}{*}{ LCA Phase } & Land Use (LU) & $\begin{array}{c}\text { Ecosystem Damage } \\
\text { Potential (EDP) }\end{array}$ & $\begin{array}{c}\text { Terrestrial Eco-Toxicity } \\
\text { Potential (TAETP) }\end{array}$ \\
\cline { 2 - 4 } & $\mathbf{m}^{\mathbf{2}} \mathbf{a}$ & Points & kg 1.4-DCB-eq. \\
\hline Raw materials & 1.2762 & CFL 3U-25 W & 0.016294 \\
\hline Manufacturing & 0.8947 & 0.8681 & 0.003145 \\
\hline Use & 23.0036 & 0.6737 & 0.136689 \\
\hline Total & $\mathbf{2 5 . 1 7 4 4}$ & 17.3464 & $\mathbf{0 . 1 5 6 1 2 8}$ \\
\hline Raw materials & 0.2971 & $\mathbf{1 8 . 8 8 8 2}$ & 0.004618 \\
\hline Manufacturing & 0.1775 & H-LED 3U-R-660-7 W & 0.000377 \\
\hline Use & 2.0966 & 0.2221 & 0.012458 \\
\hline Total & $\mathbf{2 . 5 7 1 2}$ & 0.1341 & $\mathbf{0 . 0 1 7 4 5 3}$ \\
\hline
\end{tabular}

Land use (LU) is a measure of impact on both the area involved and the number of years over which that impact occurs. The land use equivalent for CFL providing $234,000 \mu \mathrm{mol} / \mathrm{s}-\mathrm{h}$ of lighting service was 25.17 square meters per year. The H-LED lamps reduced it further still, to only 2.57 square meters. These levels were 10 times less compared to the CFL.

For ecosystem damage potential (EDP), the trend was similar. The CFL had the most impact, with 18.9 points of ecosystem damage potential over the functional unit. The H-LED offered a 1.9 point, i.e., $89.7 \%$, reduction over the CFL, greatly reducing the ecosystem damage potential.

Terrestrial eco-toxicity potential (TAETP) was measured in the 1.4-dichlorobenzene equivalents. The CFL was found to cause the release of $156 \mathrm{~g}$ equivalents of this carcinogen. Compared to this impact, the H-LED offered a reduction of $88.8 \%$, lessening the impact to only $17.5 \mathrm{~g}$-eq.

Table 6 presents the four resource-related environmental indicators that were assessed for each of the three lamp types, normalized for $240,000 \mu \mathrm{mol} / \mathrm{s}-\mathrm{h}$ of light output.

For the first of the resource-related environmental impacts, abiotic resource depletion potential (ARD), the CFL had the most impact, with $8.76 \mathrm{~kg}$ of antimony equivalents. The H-LED offered $0.85 \mathrm{~kg}$, less than 10 times that of CFL.

For nonhazardous waste landfill (NHWL), the trend was similar. The CFL had the most impact, with $40.14 \mathrm{~kg}$ of nonhazardous waste equivalents for the functional unit of $234,000 \mu \mathrm{mol} / \mathrm{s}-\mathrm{h}$ of light. 
The H-LED offered $6.55 \mathrm{~kg}$, a reduction of $83.7 \%$ over CFL, which was a large impact reduction for this metric.

Table 6. Resource-related environmental impacts of the CFL and H-LED lamp for 234,000 $\mu \mathrm{mol} / \mathrm{s}-\mathrm{h}$ of lighting service.

\begin{tabular}{ccccc}
\hline \multirow{2}{*}{ LCA Phase } & $\begin{array}{c}\text { Terrestrial Eco-Toxicity } \\
\text { Potential (ARD) }\end{array}$ & $\begin{array}{c}\text { Nonhazardous Waste } \\
\text { Landfill (NHWL) }\end{array}$ & $\begin{array}{c}\text { Radioactive Waste } \\
\text { Landfill (RWL) }\end{array}$ & $\begin{array}{c}\text { Hazardous Waste } \\
\text { Landfill (HWL) }\end{array}$ \\
\cline { 2 - 5 } & kg Sb-eq. & kg Waste & kg Waste & kg Waste \\
\hline Raw materials & 0.10410 & CFL 25 W & \\
\hline Manufacturing & 0.10622 & 1.7137 & 0.000993 & 0.001450 \\
\hline Use & 8.55496 & 3.7138 & 0.000296 & 0.000434 \\
\hline Total & $\mathbf{8 . 7 6 5 2 7}$ & 34.7152 & 0.047769 & 0.025497 \\
\hline & & $\mathbf{4 0 . 1 4 2 7}$ & $\mathbf{0 . 0 4 9 0 5 9}$ & $\mathbf{0 . 0 2 7 3 8 0}$ \\
\hline Raw materials & 0.05886 & H-LED R-660-7 W & & \\
\hline Manufacturing & 0.01322 & 2.8670 & 0.000572 & 0.001870 \\
\hline Use & 0.77973 & 0.5196 & 0.000019 & 0.000043 \\
\hline Total & $\mathbf{0 . 8 5 1 8 1}$ & 3.1641 & 0.004354 & 0.002324 \\
\hline
\end{tabular}

For radioactive waste landfill (RWL), the proportions of the reduction were nearly identical to that of the abiotic resource depletion potential. The CFL generated $49.06 \mathrm{~g}$ of radioactive waste landfill equivalents, where the H-LED lamp offered $90 \%$ savings at just $5 \mathrm{~g}$ of radioactive waste landfill generated for the same light output.

For hazardous waste landfill (HWL), the trend was similar but not exactly the same. The CFL still had the most impact, with $27.38 \mathrm{~g}$ of hazardous waste landfill generated. The H-LED lamp had a lower impact, with $4.24 \mathrm{~g}$, or $84.5 \%$, reduction.

As can be seen from Tables 3-6, the energy-in-use was the dominant LCA stage in terms of environmental impacts for both types of lamps. In addition, in comparison with CFL, H-LED used in horticulture offered much less environmental impact, even compared with white LED used for human lighting in previous publications [9-12], and for high power LED lights used in greenhouse crop production [14]. In the future, improvements in H-LED manufacturing technology will improve efficacy and reduce costs, lowering environmental impacts in almost all respects than any of the competing products on a life cycle basis, even before accounting for the energy consumed in use.

\section{Conclusions}

As a case study to assess the environmental impacts of H-LED lighting in horticultural applications, this work dealt with the identification and calculation of environmental impacts related to the raw materials, fuel, and energy input for the life cycle stages of CFL and H-LED lighting sources used for chrysanthemum cultivation.

We identified the types and amount of waste generated that affect the air, water, soil and natural resources in the process of raw material exploitation, production and use of lighting CFL lamps and red H-LED lights in chrysanthemum cultivation.

All materials, processes of production, use and emission of pollutants to the environment from each process was calculated and analyzed. The results showed that (i) the biggest environmental impacts in both CFL and H-LED lighting were from the use of electricity for lighting; (ii) the environmental impacts of H-LEDs throughout the product life cycle were much lower than that of CFLs; (iii) using H-LED lights instead of CFL for horticulture in general and for night break of chrysanthemum in particular offer not only energy savings of $70 \%$ of power consumption, but also reduce all aspects of environmental impacts. 
Author Contributions: Formal analysis, T.G.D.; Investigation, T.T.L.H. and T.G.D.; Methodology, H.K.P.; Project administration, V.T.N.; Supervision, H.K.P. and H.C.N.; Validation, T.T.L.H.; Writing-original draft, T.T.L.H.; Writing-review \& editing, H.K.P. All authors have read and agreed to the published version of the manuscript.

Funding: This research was funded by the project codes TN3/C09, and TN18/C08 of the Central Highlands Program, Vietnam Academy of Science and Technology (VAST).

Conflicts of Interest: The authors declare no conflict of interest.

\section{References}

1. Thakur, T.; Grewal, H. Influence of Photoperiodic Night Interruption on Sustainable Potted Flower Production of Chrysanthemum cv. Snowball. Int. J. Curr. Microbiol. Appl. Sci. 2018, 7, 1282-1287. [CrossRef]

2. Schroeter-Zakrzewska, A.; Kleiber, T.; Zakrzewski, P. The response of chrysanthemum (Chrysanthemum $\mathrm{x}$ grandiflorum Ramat./Kitam) cv. Covington to a different range of fluorescent and LED light. J. Elem. 2017, 22, 1015-1026. [CrossRef]

3. Liao, Y.; Suzuki, K.; Yu, W.; Zhuang, D.; Takai, Y.; Ogasawara, R.; Shimazu, T.; Fukui, H. Night Break Effect of LED Light with Different Wavelengths on Floral Bud Differentiation of Chrysanthemum morifolium Ramat 'Jimba' and 'Iwa no hakusen'. Environ. Control Biol. 2014, 52, 45-50. [CrossRef]

4. Ochiai, M.; Liao, Y.; Shimazu, T.; Takai, Y.; Suzuki, K.; Yano, S.; Fukui, H. Varietal Differences in Flowering and Plant Growth Under Night-Break Treatment with LEDs in 12 Chrysanthemum Cultivars. Environ. Control Biol. 2015, 53, 17-22. [CrossRef]

5. Thakur, T.; Grewal, H.S. Effect of duration of night interruption on growth and flowering of Chrysanthemum cv Kikiobiory. J. Appl. Nat. Sci. 2016, 8, 894-898. [CrossRef]

6. Nhut, D.T.; Takamura, T.; Watanabe, H.; Okamoto, K.; Tanaka, M. Responses of strawberry plantlets cultured in vitro under superbright red and blue light emitting diodes (LEDs). Plant Cell Tissue Organ Cult. 2003, 73, 43-52. [CrossRef]

7. Thinh, V.D.; Viet, P.Q.; Dung, H.C.; Kinh, N.T.B.; Gam, D.T.; Ha, C.H.; Khoi, P.H. Design and Fabrication of a mixed blue, red and warm white LED lighting source for plant tissue and plantlets production in-vitro. Adv. Appl. Eng. Phys. Public House Sci. Technol. 2015, 4, 258-263.

8. Gam, D.T.; Khoi, P.H.; Ha, C.H.; Ngoc, P.B.; Hung, N.K.; Binh, H.T.T.; Chuong, N.N.; Nam, L.T.; Binh, N.T.T. Anoectochilus roxburghii in vitro: Effect of led light on in-vitro growth and developmentof Anoectochilus roxburghii. J. Biotechnol. 2017, 15, 97-104.

9. U.S. Department of Energy. Life-Cycle Assessment of Energy and Environmental Impacts of LED Lighting Products, Part 2: LED Manufacturing and Performance; Technical Report; Pacific Northwest National Laboratory N14 Energy Limited: Richland, WA, USA, June 2012; pp. 1-71.

10. U.S. Department of Energy. Life-Cycle Assessment of Energy and Environmental Impacts of LED Lighting Products, Part 1: Review of the Life-Cycle Energy Consumption of Incandescent, Compact Fluorescent, and LED Lamps; Navigant Consulting, Inc.: Burlington, MA, USA, February 2012; pp. 1-46.

11. Helble, P.; Hoff, E.; Stein, A.; Welch, J. Comparative Life Cycle Assessment of Lamps Used in a Classroom at Arizona State University; Final report of Life Cycle Assessment for Civil Systems-Dr. Chester SOS 598; Arizona State University: Phoeniks, AZ, USA, 13 June 2014; pp. 3-17.

12. Chen, S.; Zhang, J. Environmental Impacts of Compact Fluorescent Lamps and Linear Fluorescent Lamps in China. In Proceedings of the International Conference on Civil, Transportation and Environment (ICCTE 2016), Guangzhou, China, 30-31 January 2016; Atlantis Press: Paris, France, 2016; pp. 1143-1150.

13. Viet Nam Ministry of Natural Resources and Environment. Notice No. 263/BĐKH-TTBVTOD on Announcement of Emission Factor of Vietnam in 2018; Asian Development Bank: Mandaluyong, Philippines, 12 March 2020.

14. Zhang, H.; Burr, J.; Zhao, F. A comparative life cycle assessment of lighting technologies for greenhouse crop production. J. Clean. Prod. 2016, 140, 705-713. [CrossRef] 